\title{
FLOOD MAGNITUDE AND FREQUENCY OF HOLLOW BROOK AT THE CULVERT ON NEW JERSEY ROUTE 35, AT NEPTUNE TOWNSHIP, NEW JERSEY
}

\author{
By Paul Dunne
}

\section{U.S. GEOLOGICAL SURVEY Open-File Report 95-417}

Prepared in cooperation with the

NEW JERSEY DEPARTMENT OF TRANSPORTATION

West Trenton, New Jersey 


\section{U.S. DEPARTMENT OF THE INTERIOR}

BRUCE BABBITT, Secretary

\section{U.S. GEOLOGICAL SURVEY}

Gordon P. Eaton, Director

For additional information

write to:

District Chief

U.S Geological Survey

Mountain View Office Park

810 Bear Tavern Road, Suite 206

West Trenton, NJ 08628
Copies of this report can be obtained from:

U.S Geological Survey

Earth Science Information Center

Open-File Reports Section

Box 25286, MS 517

Denver Federal Center

Denver, CO 80225 


\section{CONTENTS}

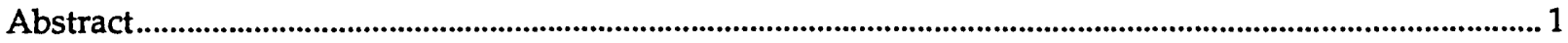

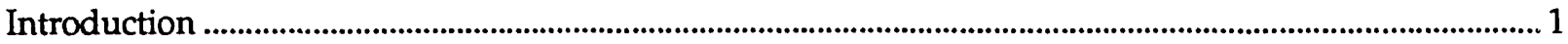

Methods for determining flood magnitude and frequency ................................................................................. 1

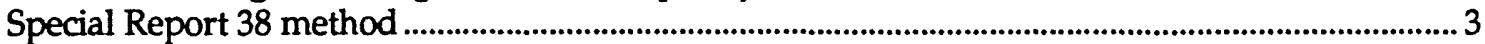

Transfer method

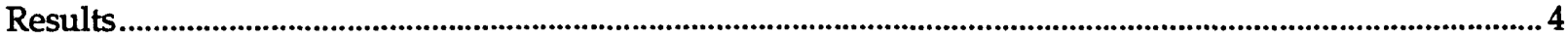

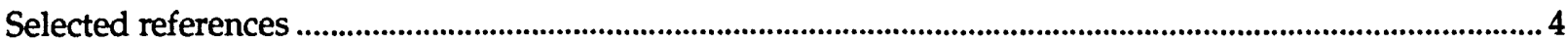

\section{ILLUSTRATONS}

Figure 1. Map showing location of Hollow Brook at the culvert on New Jersey Route 35, at Neptune Township, New Jersey

\section{TABLES}

Table 1. Explanatory variables for the flood-magnitude and -frequency methods, Hollow Brook, at the culvert on New Jersey Route 35, Neptune Township, New Jersey

2. Flood-magnitude estimates for given flood frequencies using the New Jersey Department of Environmental Protection Special Report 38 method and the U.S. Geological Survey transfer method, Hollow Brook, at the culvert on New Jersey Route 35, Neptune Township, New Jersey. 5 
CONVERSION FACTORS

Multiply

foot (ft)

mile (mi)

square mile $\left(\mathrm{mi}^{2}\right)$

foot per mile $(\mathrm{ft} / \mathrm{mi})$

cubic foot per second $\left(\mathrm{ft}^{3} / \mathrm{s}\right)$
By

0.3048

1.609

2.590

0.189

0.02832
To obtain

meter

kilometer

square kilometer

meter per kilometer

cubic meter per second 


\title{
FLOOD MAGNITUDE AND FREQUENCY OF HOLLOW BROOK AT THE CULVERT ON NEW JERSEY ROUTE 35, AT NEPTUNE TOWNSHIP, NEW JERSEY
}

\author{
By Paul Dunne
}

\begin{abstract}
The magnitude and frequency of floods at Hollow Brook at the culvert on New Jersey Route 35, at Neptune Township, New Jersey, were determined by using the New Jersey Department of Environmental Protection Special Report 38 method. Estimates of flood magnitude and frequency calculated by the Special Report 38 method, as well as drainage-basin characteristics, are included in this report. The 100-year-flood estimate is 336 cubic feet per second.
\end{abstract}

\section{INTRODUCTION}

Information on the magnitude and frequency of floods is critical to the planning and design of highway culverts and bridges. Such information is not readily available for many stream crossings in New Jersey. To fulfill this information need, the U.S. Geological Survey (USGS), in cooperation with the New Jersey Department of Transportation, began an analysis of flood data for stream-crossing sites on New Jersey streams. This report presents results of the analysis for Hollow Brook at the culvert on New Jersey Route 35, at Neptune Township, New Jersey. The culvert at milepost 24.42 at New Jersey Route 35 is located approximately 0.3 mile southeast of New Jersey Route 66 in Neptune Township, New Jersey (fig. 1). The drainage area above the culvert is $0.54 \mathrm{mi}^{2}$. A field reconnaissance was performed on March 7, 1995, to verify the locations of the drainage-basin divides and characteristics. Because the direction of storm-sewer drainage in some parts of the basin is uncertain, the calculated drainage area is approximate.

The flood-insurance study for Neptune Township (Federal Emergency Management Agency, 1983) did not include a detailed study of this stream; therefore, flood discharges were not determined previously.

\section{METHODS FOR DETERMINING FLOOD MAGNITUDE AND FREQUENCY}

Various methods for calculating flood magnitude and frequency were considered for use in determining the flood magnitudes that are likely to be exceeded at this site within a given number of years (recurrence interval). The rational method (Chow and others, 1988), New Jersey Department of Environmental Protection (NJDEP) Special Report 38 method (Stankowski, 1974), the U.S. Soil Conservation Service (SCS) Technical Release 55 (TR-55) method (U.S. Soil Conservation Service, 1986), and the USGS transfer method (New Jersey Department of Environmental Protection and Energy, 1993) were all considered for use in determining the flood magnitude and frequency of Hollow Brook at the culvert on New Jersey Route 35, at Neptune Township, New Jersey.

Flood data from nearby streamflow-gaging or crest-stage gaging stations provide a good indication of the flood magnitude and frequency that can be expected at an ungaged site, particularly if the drainage area and other basin characteristics are similar and if flood data were 


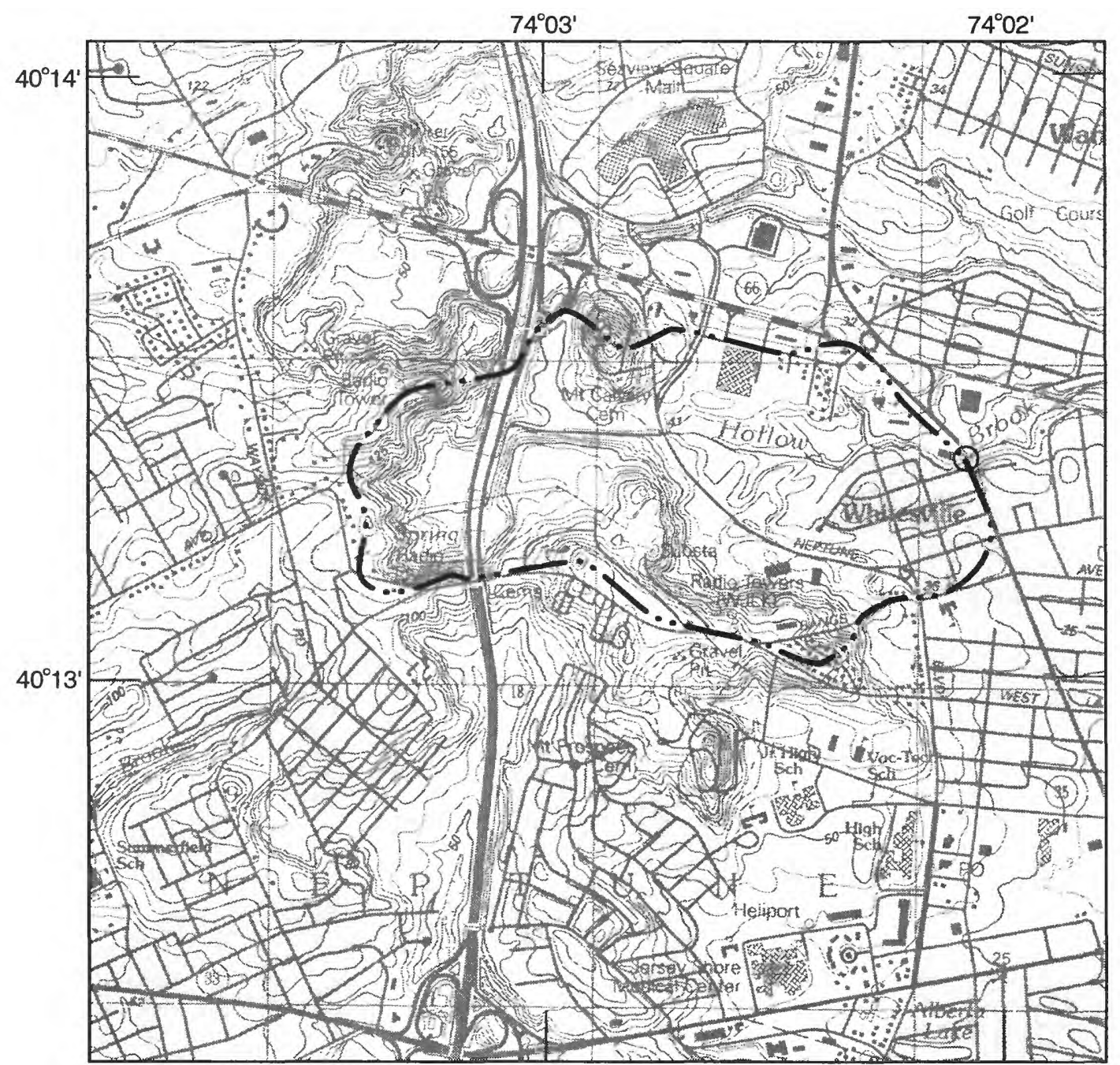

Base from U.S. Geological Survey 1:24,000 quadrangle, Asbury Park, 1989
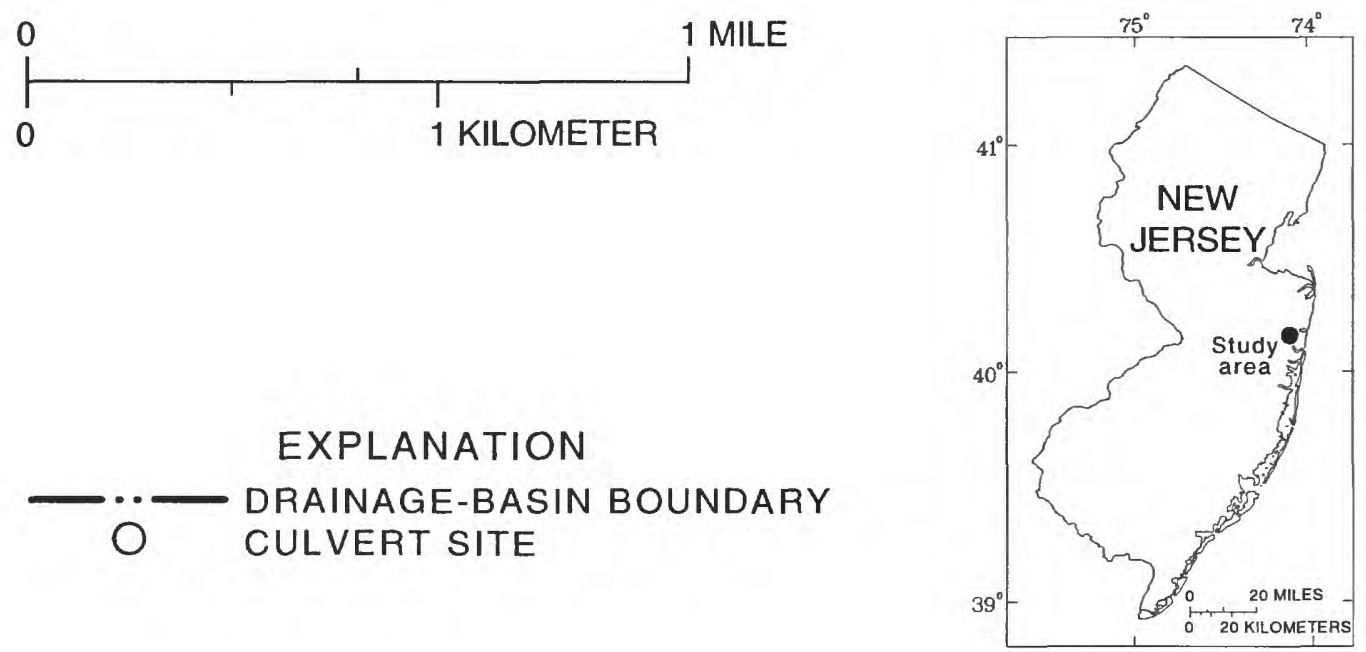

Figure 1. Location of Hollow Brook at the culvert on New Jersey Route 35, at Neptune Township, New Jersey. 
collected for at least ten years. The estimates determined by using the various methods were compared with the discharge data that were used in applying the USGS transfer method to establish whether any of the methods for determining flood magnitude and frequency were reliable.

For streams draining areas between 0.5 and $1 \mathrm{mi}^{2}$, the TR-55 method is the most frequently used method (New Jersey Department of Environmental Protection and Energy, 1993). The drainage area of Hollow Brook at New Jersey Route 35 falls within this limit. The discharge values estimated by using the TR-55 method are greater than the value estimated by using the USGS transfer method with data collected from a nearby crest-stage gage for an area (Big Brook near Marlboro, N.J.; station 01407290) with basin characteristics similar to those at the culvert on New Jersey Route 35. Newton and Herrin (1982) summarized a U.S. Water Resources Council report on estimating flood magnitude and frequency for ungaged sites by using various methods and concluded that the TR-55 method tends to overestimate flood magnitudes.

The drainage area of the Hollow Brook site falls outside the recommended range for using the NJDEP Special Report 38 method; however, values estimated by using the NJDEP Special Report 38 method are consistent with the values estimated by using the USGS transfer method with data collected at the nearby crest-stage gage (station 01407290).

\section{Special Report 38 Method (New Jersey Department of Environmental Protection)}

This method consists of the development and use of a set of regression equations for the 2-, 5-, 10-, 25-, 50-, and 100-year floods based on the watershed characteristics, drainage area, basin storage (percent area of lakes and swamps, plus 1.0 percent in order to avoid zero values), and impervious cover (based on population density). This method is recommended for use in drainage areas of 1 to $1,000 \mathrm{mi}^{2}$ (Stankowski, 1974).

\section{Iransfer Method (U.S. Geological Survev)}

The relation that is used to calculate flood estimates is based on a ratio of drainage areas raised to an exponent:

$$
\frac{Q_{P I}}{Q_{P G}}=\left(\frac{A_{P I}}{A_{P G}}\right)^{0.75}
$$

where $\mathrm{Q}_{\mathrm{PI}}$ is the design flood at the point of interest, $\mathrm{Q}_{\mathrm{PG}}$ is the design flood at the gaged point, $A_{P I}$ is the drainage area at the point of interest, and $A_{P G}$ is the drainage area at the gaged point. An exponent of 0.75 is used; the exponent is based on studies of 10-year recurrence interval floods in New Jersey (New Jersey Department of Environmental Protection and Energy, 1993). This method is recommended for drainage areas that are either less than twice or more than half the drainage area of the gaged point (New Jersey Department of Environmental Protection and Energy, 1993). 


\section{RESULTS}

The explanatory variables used in applying the NJDEP Special Report 38 method are listed in table 1. Flood-magnitude and -frequency estimates obtained by using the NJDEP Special Report 38 method and the estimates for gaging station 01407290 obtained by applying the USGS transfer method are listed in table 2. The value for the 100-year flood discharge at the culvert site estimated by using the NJDEP Special Report 38 method is $336 \mathrm{ft}^{3} / \mathrm{s}$.

\section{SELECTED REFERENCES}

Bauersfeld, W.R., Moshinsky, E.W., and Gurney, C.E., 1994, Water resources data, New Jersey, water year 1993, Volume 1. Surface-water data: U.S. Geological Survey Water Data Report NJ-93-1, 503 p.

Chow, V.T., Maidment, D.R., and Mays, L.W., 1988, Applied hydrology: New York, McGraw-Hill Book Co., 572 p.

Federal Emergency Management Agency, 1983, Flood insurance study of Neptune Township, New Jersey: Federal Emergency Management Agency, September 1983, 12 p.

Interagency Advisory Committee on Water Data, 1982, Guidelines for determining flood frequency: Bulletin 17B of the Hydrology Subcommittee, U.S. Geological Survey, Office of Water Data Coordination, Reston, Va., 28 p., 14 app.

New Jersey Department of Environmental Protection and Energy, 1993, Technical manual for stream encroachment permits: New Jersey Department of Environmental Protection and Energy, Land Use Regulation Program, Bureau of Inland Regulation, Bureau of Coastal Regulation, May 1993, 100 p., 6 app.

Newton, D.W., and Herrin, J.C., 1982, Assessment of commonly used methods of estimating flood frequency: Transportation Research Record 896, Transportation Research Board, Washington, D.C., p. 10-30.

Stankowski, S.J., 1974, Magnitude and frequency of floods in New Jersey with effects of urbanization: New Jersey Department of Environmental Protection, Division of Water Resources, Special Report 38, 46 p.

U.S. Soil Conservation Service, 1986, Urban hydrology for small watersheds: Engineering Division Technical Release 55, Washington, D.C., 162 p. 
Table 1. Explanatory variables for the flood-magnitude and -frequency methods, Hollow Brook, at the culvert on New Jersey Route 35 . Neptune Township. New Jersey

Drainage area: 0.54 square miles

Latitude: $40^{\circ} 13^{\prime} 22^{\prime \prime}$

Longitude: $74^{\circ} 02^{\prime} 04^{\prime \prime}$

Highway: New Jersey Route 35

Milepost: 24.42

U.S Geological Survey 7-1/2-minute quadrangle: Asbury Park

\begin{tabular}{lll}
\hline \multicolumn{1}{c}{ Variable } & Value & Unit \\
\hline Drainage area & & \\
Main channel slope & $=0.54$ & square miles \\
Surface storage index & $=43.0$ & feet per mile \\
Total stream length & $=1.0$ & percent \\
Population density (1990) & $=1.3$ & miles \\
Manmade impervious cover index & $=3520$ & persons per square mile \\
Lake and swamp area & $=24.3$ & percent \\
& $=0.0$ & percent \\
\hline
\end{tabular}

Table 2. Flood-magnitude estimates for given flood frequencies using the New Jersey Department of Environmental Protection Special Report 38 method and the U.S. Geological Survey transfer method, Hollow Brook, at the culvert on New Jersey Route 35, Neptune Township. New Jersey

[ $Q$, flood-magnitude estimates in cubic feet per second along with number indicating the frequency of the recurrence interval, in years; DA, drainage area, in square miles; $S$, main-channel slope, in feet per mile; St, surface storage index, in percent of drainage area; I, index of manmade impervious cover, in percent of drainage area; YR, years of record; D, distance from station used in USGS transfer method from flood site, in miles; NJDEP SR 38, New Jersey Department of Environmental Protection Special Report 38; USGS, U.S. Geological Survey; -, not applicable]

Drainage area: 0.54 square miles

Latitude: $40^{\circ} 13^{\prime} 22^{\prime \prime}$

Longitude: $74^{\circ} 02^{\prime} 04^{\prime \prime}$

Highway: New Jersey Route 35

Milepost: 24.42

U.S Geological Survey 7-1/2-minute quadrangle: Asbury Park

\begin{tabular}{lcccccccccccc}
\hline Estimating method & Q2 & Q5 & Q10 & Q25 & Q50 & Q100 & DA & S & St & I & YR & D \\
\hline $\begin{array}{l}\text { NJDEP SR 38 } \\
\begin{array}{l}\text { USGS transfer method } \\
\quad \text { Station 01407290 }\end{array}\end{array}$ & 84 & 123 & 164 & 225 & 272 & 336 & 0.54 & 43.0 & 0.0 & 24.3 & - & - \\
\hline
\end{tabular}

